viewed with the naked eye; but, being obscured as it was by the haze, the spot was distinctly visible to all.

Ongole, India, September 14

W. R. MANLEY

[Mr. Manley sends us several letters from the Madras Mail on the phenomenon ; from these we give the following extract, dated September I0:-]

A. 'Г. M. writes :- "Unlike his usual custom the sun rose this morning clothed as it were in bright blue colour, rendering the whole horizon and all beneath it of the same hue. The pure, colourless river water looked as if it was just let out of an indigo vat. Even the green fields with grass and trees about looked blue. Our whitewashed house also had a temporary change of colour. This phenomenon lasted from 6 to io a.m.

The same phenomenon seems to have been observed in Trinidad on the afternoon of Sunday, September 2. Mr. J. Arnold, writing to the Times, gives the following extract from a correspondent's letter from Port of Spain :-

"We have been having very curious weather; last Sunday, about five o'clock, the sun looked like a blue globe, and with the aid of a small telescope I saw plainly three dark spots on it. After dark we thought there was a fire in the town from the bright redness of the heavens." Mr. Arnold adds : "All my correspondents agree as to the blue colour, and several seem to have noticed the spots. This occurrence, which was heid to foretell bad weather, took place three days before the cyclone that swept Martinique."

\section{THE JAVA ERUPTION}

THE following details concerning this catastrophe have been sent by Lloyd's agents at Batavia, under date of Sept. I :-

" The past week is memorable as having witnessed one of the most disastrous and severe volcanic eruptions ever known in the Malay Archipelago. Krakatoa has again been the origin of the disturbance. On Sunday last, about 4 p.m., a series of detonations were heard proceeding apparently from the south-west Towards night these grew louder, till in the early morning the reports and concussions were simply deafening, not to say alarming. When day broke the atmosphere to the west had a sulphurous and lurid appearance, and a thin layer of fine white ash covered the ground. Towards 9 a.m. the reports died away, but about an hour later dark clouds quite obscured the sky and the sun. A heavy rain of ashes, sulphur, and dust commenced to fall, and at II a.m. this town was in pitch darkness and business totally suspended. About twelve o'clock (midday) a large wave about seventeen feet in height swept in from the sea, causing many prows and small craft to be driven ashore, but doing but little damage to the shipping in harbour. This being the dry monsoon, the rivers are low at present. The wave, however, drove an immense volume of water up our rivers, which suddenly rose so high that the banks at the river mouth were flooded and many small crafts stranded. Happily the wave subsided again suddenly, leaving the rivers almost dry, and about one o'clock the rain of ashes subsided and the atmosphere grew lighter. Shortly after 2 p.m., however, another wave, larges than the first, came rolling in from the sea. A few native fishermen were drowned by this wave, and two Europeans at Onrust also lost their lives. At Tandjong Priok the Princess Wilhelmina was within an ace of stranding, while some small crafts and prows were cast high up on land. No further damage, however, occurred in Batavia. The eruption, however, so far as we can learn, has had most fatal and disastrous effects all along the south-west coast of Java, and also on the south coast of Sumatra. We shall not probably be in possession of full particulars for some days yet, as telegraph lines are damaged and roads destroyed, but so far we can give the following particulars. The Island of Krakatoa, the summit of which peak was 2600 feet above water level, has totally disappeared below the sea, and the neighbouring Island of Dwaisindeweg is split in five parts. Sixteen new volcanic islands have been formed between Krakatoa and Sibesie, and the sea bottom in the Straits of Sunda has completely changed. In fact the Admiral Commanding-in-Chief has issued a circular stating that till new soundings have been taken the navigation of the Straits of Sunda is likely to be extremely dangerous. Anjer and lighthouse and the other lights of south-west Java have all been destroyed. The subsidences and upheavals we have alluded to caused a large wave about Ioo feet in height to sweep down on the south-west coast of Java and south of Sumatra. This wave swept inland for a great distance, thereby doing great injury both to life and property. We are here only twelve miles away from one of the points on which the wave spent its fury. The whole coastline to the south-west has changed its configuration. The inhabitants of the Island of Onrust w ere only saved from the flood which swept over the island by taking refuge on board two steamers. At Merak Government establishment the inhabitants tock refuge on the knoll, 50 feet high, but were all swept off and drowned, with the exception of one European and two Malays, who were saved. Mauk and Kramat, west side of Batavia Roads, have been laid waste, and about 300 lives lost. In Tjeringin only one house has been left standing. Both the native and European officials have perished. A rain of mud also fell at the above place, which is situated opposite to where Krakatoa Island once lay. Anjer seems to have been completely destroyed. Lloyd's subagent there wires from Serang: 'All gone. Plenty lives lost.' The dry dock at Amsterdam Island was carried away by the waves, but has since been found stranded in Middleberg Island. The Padang steamer, which left here on Sunday, returned next day to Anjer, only to find the place in ruins. The captain reports that his vessel was in great danger, owing to the eruption from Krakatoa. On his arrival at Telok Betong, his first port of call, the place was found completely destroyed. We understand that it has been submejged, but are not yet in possession of full particulars. We hear that on Monday the whole of West Java, as far as Banding, was shrouded in darkness and covered by ash rains. A telegram just in informs us that the explosions from Krakatoa were heard at Deli (Sumatra), which place is opposite Penang. The Government here, we understand, in the interest of shipping, are sending out steamers to cruise at either end of the Straits of Sunda, to warn vessels to observe caution while passing the Straits, as charts are no longer reliable. According to latest telegram from Serang we learn that in the residence of Tjeringin alone 10,000 lives were calculated to be lost. The Padang steamer just in reports that it is impossible to approach to the place where Telok Betong once was situated, owing to the sea being filled with pumice stone and mud. In some parts of Sumatra Straits the pumice stone is seven to eight feet deep."

\section{THE BRITISH ASSOCIATION SECTION C-GEOLOGY}

On some Fossil Fish Remains found in the Upper Beds of the Yoredale Series at Leyburn, in Yorkshire, by James W. Davis, F.G.S. - The red limestone forms the upper part of the main limestone of Phillips, being separated from it by only one foot of shale or plate. It is about 100 feet below the millstone grits, the intermediate beds being composed of grits and shales with one bed of limestone about 16 or 18 feet thick. A peculiar aggregation of fish remains has been discovered in the red beds by Mr. Wm. Horne of Leyburn, They comprise nearly forty species, the majority of which are peculiar to the beds; others like Cladodus and Petalodus are common to the Mountain Limestone, and do not appear to differ either in size or otherwise from those of the lower massive limestone. The representatives of the genera Psamodus, Cochliodus, and Polyrhizodus, which are found abundantly in the lower limestone, and are of great size and importance, are in this locality comparatively small and rare, and appear to indicate that the fishes they represent were gradually becoming extinct. Their representatives are not known to occur in the superimposed Millstone Grits either in this locality or any other. There are in addition species of $M \mathrm{ega}$. lichthys and Pleurodus, which are characteristic of the coal measures. The presence of so varied a fauna naturally leads to the inference that the circumstances under which they existed were not those usually characteristic of the aggregation of limestones, but rather indicate a shaliow or shore deposit with occasional influxes of fresh water. Megalichthys and Pleurodus are fishes which in the coal measures probably lived in fresh ox brackish water; and though they may have been adapted to exist in marine conditions, the occurrence of beds of sand and shale intercalated with the thin limestones of the Yoredales evidently shows the proximity of land, and it is probable that they were carried to their present position by rivers, and there deposited with the marine forms with which they are associated. The supposition that the water was brackish may account for the small size of some of the genera already mentioned and their final extiuction in the grits and shales which succeed the limestone. The great fishes whose remains are found in the lower lime 
stone, represented by Ctenacanthus, Orthacanthus, and others, are absent, the only species hitherto found being those of the curious Cladacanthus and Physonemus.

On the Occurrence of the Remains of Labyrinthodonts in the Yoredale Rocks of Wensleydale, by James W. Davis, F.S.A., F.G.S. - Some bones of the leg of a Labyrinthodont were discovered by Mr. Horne and described by Prof. L. C. Miall in the Quarterly Fournal of the Geological Society, vol. xxx. p. 775 . They were found in a dark coloured flagrock above the Harmby Quarry, which also extends with an easterly dip to the Harmby railway cutting. The same flagrock is also found behind Ley. burn and the Shawl, and in that locality it has been extensively quarried. In addition to the leg-bones already mentioned, others have been found in the same flagrock, but separated by considerable distances, so that it is not probable that they belonged to the same Labyrinthodont. In the railway cutting a portion of a cranium was found. It is $I^{\circ} 9$ inch in length and $\mathrm{I}_{4} 4$ in breadth. A number of sutures, not very well defined, seem to indicate that the bone constituted the back part of the skull. The third specimen was found in the quarries beyond the Shawl north-west of Leyburn, and exhibits casts of the jaws of another Labyrinthodont. Each ramus is about three inches in length; they have been disturbed and displaced. The external surface of the jaws was ornamented with a reticulated arrangement of tubercles, an impression of which is preserved in the specimen. Along the margin of the impression of the alveolar portion of one of the rami there is a series of impres. sions which appear to have been caused by small pointed teeth.

Section across the Trias recently exposed by a Railway Excavation in Liverpool, by G. H. Morton, F.G.S.-During the last eight years a very important section of the Triassic strata has been exposed in Liverpool, by excavations for widening the line of the London and North-Western Railway Company. The section presents a solid mass of sandstone on both sides of the new railway cutting from Lime Street Station to Edge Hill Station, a distance of 2300 yards from east to west. The beight of the rock on each side varies. The strata exposed belong to the Keuper and Bunter formations. The Pebble Beds of the Bunter crop out for 914 yards along the east of the cutting, but do not contain any marl partings, and not a single pebble of any kind has been noticed. Only two faults occur along the whole length of the Pebble Beds exposed, and they are of very little importance. The subdivision ends at Smithdown Lane, where there is a fault with a downthrow to the west, which brings in the upper mottled sandstone, the highest member of the Bunter formation, where it is not represented on the map of the Geological Survey, or the fault recorded. The Upper Mottled is a fine-grained, soft, bright red sandstone with grey streaks, and as it readily crumbles into sand is never hard enough for building purposes. It crops out to the west from Smithdown Lane to University College, when a fault throws down the strata about 600 feet and brings in the Keuper sandstone, which is 400 feet thick, and interstratified with thin beds of marl. The highest beds of the Keuper are at the College ; lower strata containing the beds of marl crop out from beneath, and are thrown down to the west by faults three times in succession, when the basement beds crop up in Lime Street Station. The section shows that all the fanlts throw down the strata to the west and bring in higher beds in that direction. It also shows the exact position of the fault between the Bunter and Keuper formations, which was not known before. The position of the Keuper, as a wedge-shaped mass of sandstone, with the Bunter formation faulted against it on the east and west, is of great local interest, and it is easy to understand how the succession of the strata has not been satisfactorily explained before in the absence of any such a continuous section as that described. The remarkable absence of faults in the pebble-beds has an important bearing on the construction of the Mersey Tunnel, which will have to be carried through these beds along its entire length. The section shows that while faults are numerous in the Keuper sandstone, which was frequently fractured during subsidence into a depression, the pebble-beds are very little faulted. A few days ago, when under the Mersey, I did not find a single fault either in the tunnel or in the heading beneath.

Recent Opinions on the Loess Deposits of the Valley of the Rhine as Evidence of a "Great Post-Glacial Flood," by Mark Stirrup, F.G.S., adversely criticises recent opinions of Mr. H. H. Howorth, F.S.A., as to the mammoth in several of the superficial deposits proving a "great Post-Glacial flood." The facts connected with the loess deposits of the Rhine Val- ley are not consistent with the interpretation given to them by Mr. Howorth, nor is the assumption that the materials of the loess were derived from volcanic mud-streams borne out by the evidence. The author considers Mr. Howorth has failed to prove his postulate that not only the extinction of the mammoth but the existence of several superficial or Post-Glacial deposits were due " to a sudden catastrophe involving a great diluvial movement which extended over the larger part of the northern hemisphere, and accompanied by an equally sudden and violent change of climate," and the author considers the whole of the evidence adduced by Mr. Howorth as unsound and inconclusive. He regards Mr. Howorth's attempt to resuscitate some of the obsolete doctrines of Cuvier and Buckland as a retrograde movement in the history of geology.

Master Divisions of the Tertiary Period, by Prof. Boyd Dawkins. - The classification of the Tertiary rocks sketched out some fifty years ago and since then altered in no important degree is out of harmony with our present knowledge, and the definitions of the series of events which took place in it has been greatly modified by the process of discovery in various parts of the world. The terms Eocene, Miocene, and Pliocene no longer express the idea of percentages of living species of fossil mollusca upon which they were founded, and PostTertiary, Quaternary, and Recent are founded on the assumed existence of a great break comparable to that separating the Secondary from the Primary or Tertiary periods which is now known not to exist. The author proposed a classification of the Tertiary period in Europe, by an appeal to the land mammalia, and since that time his definition has been found to apply equally well to the Tertiaries of Asia and the Americas and to the late Tertiaries of Australia. He stated that the forms of life in the rocks have changed at a very variable rate, and in direct proportion to their complexity of organisation, the lower and simpler having an enormous range, while the higher and more complex have a much narrower range and are more easily affected by the change in their environment.

On a Boulder from the Chloritic Marl of Ashwell, Herts, by H. G. Fordham.-Boulters found in these marls, in the socalled coprolite workings in Cambridgeshire and the neighbouring counties, are usually little more than pebbles. The boulder now described measures $12 \times 9 \frac{1}{2} \times 5 \frac{1}{2}$ inches. It is somewhat triangular in general form, and is much rounded and worn. The material, according to Prof. Bonney, is a quartz-felsite. The author attributes its origin to its being brought to its present position by floating ice.

Preliminary Note on the Furiher Discovery of Vertebrate Footprints in the Penrith Sandstone, by G. V. Smitb. - The specimens were obtained from a quarry opened out by the Settle and Carlisle Railway, situated on the slope of the hill, north of the highway from Penrith $t$, Alston, and about three and a half miles from Penrith, the sandstone is strongly current bedded, and is largely used for building purposes; these sandstones are older than the magnesian limestone. The impressions indicate several distinct forms of vertebrates.

On a Supposed Case of Metamorphism in an Alpine Rock of Carboniferous $A g$, by Prof. T. G. Bonney, M.A., F.R.S.- At the base of the Carboniferous series in some parts of the Western Alps is a conglomerate called the Poudingue de Val Orsine, the matrix of which abounds in mica, and is supposed by some geoloyists to exhibit true foliation. In the Alps there is always an abrupt transition from the comparatively unmetamorphosed rocks of known geological age to the true schists and gneisses of unknown but certainly far greater antiquity, and nothing short of the clearest proof would justify us in considering any of these crystallised foliated rocks as altered Devonian or Silurian, even though the latter term be used in its most extended sense.

On the Geological Age of the North Atlantic Ocean, by Prof. Edward Hull, LL.D., F.R.S., \&c., Director of the Geological Survey of Ireland. - In this paper the author made use of three leading formations as factors in his inquiry, viz. the Archrean (or Laurentian), the Silurian (chiefly the Lower Silurian), and the Carboniferous. He considers that throughout the Archæan, or Laurentian, the Lower Silurian, and the Carboniferous epochs, the regions of North America, on the one hand, and of the British Isles and Western Europe were submerged, while a large part of the North Atlantic area existed as dry land, from the waste of which these great formations had been built up; and he urged that if such were the case, the doctrine of the permanency of oceans and continents, as tested by the case of the North Atlantic, falls to the ground.

Dyas versus Permian, by Rev. A. Irving, B.Sc., B.A., 
F.G.S.-This subject is brought forward for discussion both as having a special local interest, and on account of the international importance of the subject in view of the Berlin Congress next year, and the progress of the geological map of Europe. The author, referring to previous papers in the Geolo. gical Magazine during the year I882, in which strong reasons were given for abandoning the threefold division of the so-called Permian system, and to the discussions raised in the same periodical, maintains that the "Permian system" of Murchison, which represents the group of strata as marked by three stages, is inapplicable to the English rocks of Post-Carboniferous age. The term "Permian" has only a local and subordinate value, and scarcely applies even to the whole Russian area in which these strata are developed. He considers that the application of the "Permian system," as propounded by Murchison, to the Post-Carboniferous rocks of Central Europe is no longer tenable, any more than is its application to the British series, as the author has shown elsewhere.

On the Coloration of some Sands, and the Cementation of Siliceous Sandstones. By the Rev. A. Irving, B.A.-In the first part of this paper attention is drawn to the occurrence of certain green-coloured sands which are frequently met with below the peaty layers, at the heads of the small valleys, in the Upper Bagshot sands. The local and exceptional nature of these green deposits, and their relation to the decomposing vegetal matter which has overlain them for a long period of time, suggest the connection of the green colour with the decomposition of vegetation. Chemical analysis of these sands shows that the green colour is in no way connected with any of the ordinary green minerals which enter into the formation of rocks, but reveals the organic origin of the colouring matter. In the second part of the paper attention is drawn to some recent investigations by the author of the origin of the siliceous cementing material of the sarsen stones.

Note on the Nagel Flue of the Rigi and Rossberg. By Prof. T. G. Bonney, M.A., F.R.S. - The author called attention to the following points in regard to the conglomerate of these mountains :-(I). That the pehbles were not seldom indented by mutual pressure; $(2)$ that the pebbles in this district consi ted mainly of grits and limestones from the Secondary and perhaps early Tertiary series of the Alps, with a variable amount of a reddish granite (of whose locality he was ignorant). He considers there was a close analogy between the Bunter conglomerate and the nagel flue, the former also resembling the British Old Red Sanditone, and a part of the Calciferous sandstone series in Scotland. As these three were admittedly freshwater deposits, he argued that the Bunter series (the parts of which had some resemblance to the ordinary molasse) should be reckoned among the true fluviatile or fluvio-lacustrine deposits.

Notes on Geological Sections within Forty Miles' Radius of South. port. By C. E. De Rance, F.G.S.-The sections in Silurian works of the Lake District and North Wales within the radius are described, also those in the Carboniferous limestone, coal measures, Permian, and the Triassic rocks, especially the Keuper sandstones and worls around Southport. The sections in the glacial drift of West Lancashire and Cheshire are menticned, and the sequence and character of the overlying postglacial beds. Southport i; built upon blown sand resting on peat, which is 79 feet below the surface at the sea-coast, rising inland to the surface; the whole series rests on the Keuper marls, which have been bored into to a depth of 187 yards at the Palace Hotel, Birkdale, without finding the baee. Fragments of gypsum and pseudomorphous crystals of salt occurred in the boring. The section in the Mersey tunnel, now in course of erection, was alluded to.

On the Pre-Cambrian Toneous R'ocks of St. David's, by Prof. J. F. Blake, M.A., F.G.S. - The rocks below the Cambrian conglomerate have been described by Dr. Hicks as bedded rocks belonging to three distinct periods. The same rocks have been recently asserted by Dr. Geikie to be partly Cambrian and partly intrusive. The author contends that they are Pre-Cambrian in age, but form a very complete volcanic series, which may well be designated the Dimetian. The basis of the series is the Dimetian granite, serving as the core. This is surrounded by the more acid rocks, as the quartz. felsites and the felspar porphyries (the so-called Arvonian), and the more outlying portions consist of very varying materials, chiefly rough ashes or agglomerate breccias-on the east side finely bedded "halleflintas," and on the north side many basic lava flows. These are the so-called "Pebidian." The arrangement of these rosks shows the characteristic irregularity of volcanic rocks, and though many portions are bedded, they have no dominant strike over the whole district. The Cambrian series commencing with the conglomerates is quite independent and hangs together as a whole. In no case can a continuous passage be proved from the one series to the other; the junction is in most cases a faulted one, and at the places where this is not so, the conglomerate lies on different beds of the volcanic series.

On a Coral Atoll on the Shore Line at Arvigland, near Dumfries, Scotland, by James Thomson, describes a band of Carboniferous limestone, with corals of several genera, which form seventeen coral reefs, extending through a depth of 400 feet of strata.

On the Former Physical Condition of Glendale, Northumberland, by G. P. Hughes, describes the River Till, as once filling this valley, and forming a lake, on the site of which occurs peat, forest beds, grey clays, with Bos urus, Cervus megaceros, and red stag, and gravels, resting on boulder clay.

Additional Notes on Anthracosaurus Edgei, by W. H. Baily, describes a large Sauro-Batrachian from the lower coal measures, Jarrow Colliery, near Castlecomer, co. Kilkenny.

On Basalt apparently overlying Post-Glacial Beds, co. Antrim, by W. T. Knowles, describes a mass of basalt twenty yards in length, lying on sands and gravels; probably is a glacial erratic.

On the Geological Relatives and Mode of Preservation of Eorson Canadense, by Principal Dawson.-The oldest known formation in Canada is the Ottawa gneiss, or fundamental gneiss, a mass of great but unknown thickness and of vast area, consisting entirely of orthoclase gneiss imperfectly bedded, and destitute of limestones, quartzites, or other rocks, which might be supposed to indicate the presence of land surfaces and ordinary aqueous deposition. It constitutes the Lower Laurentian of Logan, and may be regarded either as a portion of the earth's original crust, or as a deposit thereon by aqueo-igneous agency, and without any evidence of derivative deposits. Succeeding it is a formation of very different character, though still belonging to the Lower Laurentian of Logan. It may be named the Glenville series, and includes beds of lime tone, quartzite, tin ore, graphitic and hornblendic schists, with local beds of pebbles; it is in one of these great limestones that Eozoon occurs. The Grenville series give distinct evidence of ordinary atmospheric erosion of the older rocks, and of ordinary aqueous as well as organic deposition. The author hopes to exhibit specimens, now in the McGill University, to the Association.

On the Topography and Geology of the Troad, by T. S. Diller.

- The Liparites are older than the Andesites, rocks that are probably pre-Cambrian from the base of the older sedimentary rocks, which are much altered and often highly crystalline. The more sedimentary rocks are also partially crystalline; they are less important in determining the phy:ical geography. Positions of streams have varied much, but the coast-line has probably cbanged little since the days of Troy. Mount Ida is an anticlinal with a very short axis, and is almost a dome, the summit of which has been denuded.

\section{SECTION D-BIOLOGY}

\section{Department of Zoology and Botany}

On the Origin and Development of the Rhinoceros Group, by Messrs. Scott and Osborne.-The very extensive series of Tertiary lake deposits in the north-western United States have afforded these geritlemen material for some generalisations on this sub. ject. Their conclusions are as follows:-That from the Rhinoceros gronp of the Middle Eocene there diverge three distinct lines, one represented by the forms still living in the Old World, the other two exclusively American and extinct. The first of these lines is continued into the Upper Eocene formation by the genus Amynodon. In this form the rhinocerotic features of the skull are slightly more marked; the lower canines are somewhat more procumbent and have caused the atrophy of the lower incisors. The digits are four in the manus and three in the pes. In the Lower Miocene follows the genus Aceratherium, which, retaining the number of digits found in Amynodon and many lophidont skeletal characters, is yet an unmistakable rhinoceros. From Aceratherium, again, we get two diverging lines, one belonging to the Old World, the other to the New. These authors think that very probably Acera. therium originated in America, and migrated to Asia in early Miocene times. In the Old World it gave rise to the horned series of genera, probably beginning, as suggested by Cope, with 
Ceratorhinus. In America are found a number of large rhinoceroses in the Loup Fork deposits of the River Platte, which are variously designated as Uppermost Miocene and Oldest Pliocene. These have left no successors unless $R$. inenius of Le Gros should turn out to be an Aphelops. In brief, the rhinoceros line branched off from the Lophiodontidæ in America during the Middle Eocene, in early Miocene times the genus Aceratherium migrated to the Old World, and there gave rise to the horned genera, which still live there, as well as the larger species which became extinct in the Post-Pliocene. The second line mentioned is represented by the curious genus Diceratherium. The third line is that of Hyracodon, small hornless animals of the Miocene. This retains the full set of incisors and canines in both jaws, but with rhinoceros-like premolars and molars. Many lophidont characters are still retained.

The Polymorphism of Alcyonaria, by Prof. Marshall. - The author directed attention to the occurrence of tentaculato-zooids in two members of the group Pennatulidæ-the first the variety of Pennatula phosphorea, known as aculeata, and the second a new species of Umbellula, $U$. gracilis, obtained in the Faroe Channel during the Triton dredging expedition in 1882 . In the first case the tentacles, which vary from one to five in number, are fused together to form a conical spire strengthened by very stout calcareous spicules, and projecting a considerable distance beyond the mouth. In the case of $U$. gracilis the tentacle is single, and differs from that of all other pennatulid zooids in presenting a fringe of pinnules along each side identical with those of the typical polyps. . The morphological importance of this unitentacular condition was discussed at some length, the single tentacle being shown to have constant anatomical relations and to correspond to the single tentacle present in the young embryos of Actinia mesembryanthemum. In conclusion, arguments were adduced against Prof. Kölliker's statement that Umbellula is one of the more primitive genera of Pennatulidæ.

The Differences between the Males and Females of the Pearly Nautilus, by Mr. A. G. Bourne, B.Sc. - The author bases his observations upon the dissection of two sfecimens, male and female respectively - both adult and well preserved-of $N$. pompilius obtained by Prof. Lankester for the museum at University College, and a specimen of $N$. macromphalus placed in his hands for examination by Prof. Hubrecht, of Utrecht University. The author regards the tentacular lobes as homologous with the arms of a Dibranch, while the tentacles probably represent the suckers, this view, which has already gained considerable ground, receiving very strong support from the hectocotylised condition which the author describes. Eight tentacular lobes may be recognised, four internal, two superior, and two inferior, the latter two being fused together, and four external, the two superior being fused to form the "hood," and the two inferior completing the external ring. In the male four tentacles of the left superior internal lobe become hectocotylised, while the corresponding four upon the opposite side exhibit an exactly similar modified condition, though in a very slight degree, forming a most interesting example of a "rudimentary organ." In the male the inferior internal lobes are present in a very much reduced condition.

Budding in Polyzoa, by Prof. Haddon.-This anthor asserted that according to most observers the buds in ectoproctous Polyzoa are derived solely from the endocyst, or according to Joliet, from the endosarc (funicular tissue). It is possible that a combination of these views may be the more correct, since the development of the bud itself appears to prove that several distinct tissues are implicated, and that as a matter of fact all the three embryological layers are concerned in this process.

On a Young Specimen of the Grey Seal (H. gryphus) from Bos castle, Cornwall, by Prof. Lankester.-Prof. Lankester bad the good fortune to find a specimen of thi; seal at the above place about a fortnight ago. He carried it about a quarter of a mile to a more sheltered place, but found it in the original place the next morning. As the specimen was not more than twentyfour hours old, was very weak, and could not swim, it is very probable that the mother had carried it curing the night. The animal was taken and fed on milk; he was sent to the Zoological Gardens, and when last heard of was doing well. Mr. Cordeaux said it was extremely interesting that this specimen had been found, as previously it had not been seen so far south. Prof. Moseley remarked that the dislike of young seals to the water had probably some connection with their descent from ancestors which inhabited the land quite as much as the water.

On Wool Plugs and Fertilised Fluid, by Mr. Duncan Matthews.-This paper describes in detail a series of experi- ments undertaken with the object of testing the filtering action of cotton wool plugs upon the atmosphere, and the consequent possibility of permanently preserving fluids sterilised in flasks plugged with wool. The author found, after a long series of experiments, that sprayed water carrying germs could pass through wool plugs as well as between it and the glass, when an inward current was produced by the cooling of the flask. He therefore sees no reason why air should not in the same manner carry germs through or alongside the wool. As an experimental fact, he found this to be so in a very large percentage of his experiments. All the experiments related to one kind of bacterium, the hay-bacillus.

The President then introduced the next four papers, which all related to various phases of the germ-theory, by a few remarks on bacteria. Micrococcus, bacillus, spirochœete, spirillum, and leptothrix were briefly spoken of, and the terms saprogenous, cromogenous, and pathogenous explained; the first of these papers was then read.

On the Germ Theory of Disease from a Natural History Point of View, by Dr. Carpenter.-Dr. Carpenter stated that many of the existing genera and species of animals and plants were altogether uncertain, that as fresh knowledge was gained, so it was found necessary to modify our accepted views ; this especially holds good with genera which have great power of adapting themselves to various circumstances, and which consequently produce numerous variations. This power of modification, the author stated, was much more marked in the lower than in the higher forms of either kingdom, and was especially found in bacteria. The author then cited the case of the germ producing smallpox, in which he stated the germ had undergone such a modification, that whereas two centuries ago the disease was very severe, and known as "black-pox," it now existed only as a mild disease. During the last siege of Paris, however, the conditions were such that the germ reverted to its original form, and produced the same severe disease as two centuries ago. Many facts were brought forward to confirm this view.

On some Cell Contents in Coffee and other Plants, by Marshall Ward. - The author has for some time past been engaged in researches among the fungi, particularly those which attack living plants; and his attention was necessarily directed to cell contents of the host plants; among uthers the cells of Coffia, Cinchona, Pavetta, and Canthium, and one or two cryptogams have received special attention. The present paper refers particularly to one class of bodies found in the cells of the cultivated species of Coffea-C. arabica, C. liberica, \&c. Certain fatty bodies, mixed with proteids, found in the endosperm, are traced into the embryo and seedling, and their reactions and changes noticed. In the leaves, cortex, and other soft parts of the mature plant are found "fat-bodies," under circumstances which compel the author to conclude that they are the result of constructive activity, and not products of destructive metabolism. These "fat-bodies" consist of varying mixtures of fats and other substances, prohably, in part, proteid, and show considerable similarity to the fatty masses of the endosperm. Details are given of their reactions and changes, and the author believes that they represent temporary stores, to be worked up further in the construction of higher bodies.

On the Closed Condition of the Seed Vessel in Angiosferms, by Alexander S. Wilson, M.A., B.Sc.-Flowering plants may be divided into two classes, according as their seeds are contained within a closed seed vessel, or are exposed without any such covering. The former, having their seeds included in a pod or pistil, are called Angiosperms or cover-seeded; and the latter, on account of their naked seeds, Gymnosperms. The Angiosferms, which form by far the more important division, embrace most of the common plants which make up the bulk of our flora, and are universally regarded as the more bighly organised of the two. Corresponding to the lower degree of organisation, Gymnosperms (yew, cypress, fir, \&c.) appear earlier in the geological strata, and are largely represented in a fossil state. The pod of an Angiospern, such as that of a wallflower, is composed of metamorphosed leaves termed carpels. In nearly every instance these leaves are so united as to form a completely closed case enveloping the young seeds, At first sight it would seem as if the presence of such a covering were a disadvantage, for before the young seeds or ovules can develop to maturity they require to be fertilised. The process of fertilisation is effected by the agency of pollen dust, which is brought to the flower either by the wind or by insects visiting the flower in search of honey. Now in the case of Gymnosperms, where the seeds are exposed uncovered, this pollen dust, 
if blown by the wind, simply alights on the surface of the seed and fertilises it directly. In plants with covered seeds, on the other hand, the pollen cannot gain direct access to the ovules, but can only fall on the surface of the envelope formed by the carpellary leaves. This covering has to be penetrated before fertilisation of the seeds can be effected. For this purpose several adaptations of tissues, modifications of structures, and changes in the position of the ovules are rendered necessary, all of which might easily be dispensed with were the seeds exposed as they are in Gymnosperms. It can hardly be supposed that all this specialisation, whereby the process of fertilisation so simply performed in Gymrosperms becomes complicated by being broken up into numerous subsidiary processes, should be calied into play unless some very important end were to be attained by the presence of a completely closed pistil. What then is the rôle of the pistil? 'The young seeds are the most vital parts of the vegetable organism. Composed of delicate cells, containing much nitrogen and phosphorus, they may be said to constitute the chemical and physiological wealth of the plant. On this account they must be carefully guarded from any external influence that would degrade their chemical constitution or lead to a misappropriation of the nutritious matters they contain. Now it is well known that the leaves and stems of nearly all plants are subject to the attacks of parasitic fungi. The spores of these parasites germinate on the leaves of the plant on which they alight, and appropriate its juices to their own use, as, for example, in the case of the fungus which occasions the potato disease. All kinds of moulds, putrefaction, and fermentation are in like manner produced by the development of spores falling frsm the atrnosphere which have found a favourable soil for their growth. Now a more suitable pabulum or nidus for the growth of mould germs can hardly be imagined than that which would be afforded by the immature ovules, seeing that in them is collected a large amount of easily assimilable matter destined for the nutrition of the embryonic plant. There can be little doubt then that the disadvantages which the pistil brings with it, and the higher organisation thereby entailed, are more than compensated for by the security which it gives against the entrance of fungus spores. The pea pod is in fact the counterpart of the hermetically sealed or stoppered flasks, in which Tyndal and Yasteur performed their well known experiments on the preservation of organic fluids against putrefactive changes. These observers found that it was possible to preserve beef tea or other organic infusion for any length of time, provided no air was admitted to the flask, or if care were taken to filter the air from all organic germs by passing it through cotton wool, \&c., before allowing it to have access to the infusion. The pistil of a flower then may be regarded as analogous to the flask in these experiments. The loose cellular substance of the style, and the acid secretion on the stigma, may in like manner serve to filter the air before it reaches the ovules contained within the ovary. At any rate the air must pass through the substance of the carpels before it can reach the ovules. ${ }^{1}$ When this fact is viewed in connection with the experiments of Van Tieghem, which show how difficult it is to effect the direct fertilisation of ovules with pollen, owing to the constant appearance of microscopic fungi, a new light is thrown on a vast number of vegetable and animal structures. The same principle operates not only among phanerogams, but even among the cryptogams; nor could a principle of such general application in the vegetable world have failed to play an important part in the animal kingdom. It is remarkable then to find that within the cup of the commonest wild flower we have the results of recent scientific research anticipated, the benefits of the antiseptic system as completely secured as by modern surgery, and a parallel between nature and art which agrees even to the minutest detail.

Protoplasmic Continuity in the Floridea, by Thomas Hick, B.A. B.Sc-The author has made an extensive series of observations on a large number of species belonging to the more important genera of Floridea, with special reference to the question of protoplasmic continuity. He finds in all the sfecies examined that there is such a continuity, and that of the clearest and most definite character. In the simpler filamentous types, such as Petrocelis cruenta and Callithamnion Rothii, the protoplasm of each cell is united with the protoplasm of contiguous cells by means of a

$x$ This view of the function of the carlels is corroborated by the fact $a b-$ served in the case of Reseda, the carpels of which open soon after fertilisa tion. After dry weather an accumulation of sand and dust frequently takes place within the ovary cf licsel-... fine protoplasmic thread. This obtains throughout the whole plant. In the more complex types, such as Callithamnion roseum, $C$. arbuscula, and C. tetragonum, the arrangements for continuity are of a more elaborate character. The contents of the axial cells are not only united with one another, but also with those of the cortical cells, however numerous these may be. The cortical cells also display continuity inter se. Ptilo'a elegar's is a most instructive form, as here the connective threads may be easily traced from the tips of the ultimate branchlets to the base of the stipes of the frond. As the threads become older, they increase in thickness, thus showing that they are not merely temporary or effete structures. On the stouter connecting cords a scrt of ring or collar is developed at about the middle point, and over this is stretched, in some cases, a delicate diaphragm. The behaviour of both ring and diaphragm when treated with microchemical reagents, is similar to that of the ordinary protoplasm.

On Peripatus, by Adam Sedgwick.-Mr. Sedywick showed living specinens of this animal, and briefly described them.

Some newly-discovered Localities of the Rare Slatg 7'estacella hallotoidea, by E. J. Lowe, F.R.S. - This rare and hitherto extremely local nest-eating slug has recently been found in various places in Monmouthshire and South Wales. Shirecester Hall, Shirenewton Village, Tatton Court, Hardwick, Chepstow, Cardiff, and various other places, were mentioned as producing more or less abundant quantities of this interesting creature.

\section{Department of Anatomy and Physiology}

On the Relations of Protoplasm and Cell-wall in the Vegetable Cell, by F. O. Bower. - After tracing the history of this subject, it was concluded that it has now been demonstrated with as much certainty as is possible by the wse of microchemical and staining reagents, that in certain cases, the number of which is now constantly being increased, there is a direct connection between the protoplasmic bodies on opposite sides of cell-walls, and that this connection is established by means of fine strings of protoplasm which, in the cases observed, run nearly transversely through the walls. The question remains whether this is the only mode of permeation of the cell-wall by protoplasm. The author could not accept it as proved as yet that any further permeation of the cell-wall by protoplasm, as a reticulum or otherwise, really exists, but he brought forward certain grounds for regarding such a permeation as possible or even probable, taking into account chiefly those phenomena observed in free cell. walls, in order thereby to avoid any confusion with connecting strings, such as those already proved to exist:-I. The strings already observed vary greatly in thickness, from the well marked to the indistinguishable; thus we have evidence of the existence of strings which would probably not have been $r \in$ cognised were it not for comparison with other examples. Further, it has been shown, in the author's paper on plasmolysis, that protoplasm may be drawn out into strings so fine as to defy definition even by high powers of the microscope ; thus there can be no objection on the ground of the small size of the hypothetical strings or reticulum. 2. Those cases in which a perforation of cell-walls has been demonstrated are those very cases in which a most efficient physiological connection is required. There is no reason why a less obvious permeation should be denied where the requirements are less, but by no means absent. 3 . There is a priori probability of some form of permeation of cell-wall by protoplasm if Strasburger's account of the growth of cell-walls be correct. 4. A strong argument in favour of such general permeation of walls by protoplasm is found in the existence of important chemical changes in the substance of certain cell-walls at points at a considerable distance from the main protoplasmic body, e.g. formation of cuticular substance, wax, \&c., which differ fundamentally from cellulose, are insoluble in water, and are apparently formed in the wall itself. The tendency of recent observations is to show more and more clearly how close the connection of protoplasm with the important chemical changes in the plant is ; thus it appears probable that protoplasm is present in some form or other in the cell-wall. Reasons were also given for thinking that the exposure to air is not an important factor in the above changes. These and other considerations show that though this permeation of the wall cannot be accepted as proved as yet in any one case, still the subject deserves more clcse attention than it has yet received, while it may be expected that the application of new methods may produce definite results bearing on this very important question.

On the Occurrence of Chlorophyll in Animals, by C. A. MacMunn, M.D., F.C.S. - The difficulties attending the recog- 
nition of chlorophyll in animals was first referred to, and the writer stated that he had based his conclusions as to the identity of animal and vegetable chlorophyll on the fact that the wavelengths of the centres of the bands of the same solutions of animal and vegetable chlorophyll are the same, and that the wave-lengths of the centres of the bands are the same when the same reagent is added to the respective solutions. Without committing himself to accepting the views of Kraus or Sorby, he applied the term chlorophyll to that colouring matter, or mixture of colouring matters, which can be extracted out of green leaves, such as those of Primula, by means of alcohol or alcohol and ether. The colouring matter, to which the writer has given the name "enterochlorophyll" (Proc. Roy. Soc. 226, 1883), and which can be extracted from the liver or other appendage of the enteron of invertebrates, was shown to be probably produced by, and in, the body of the animal, and for certain reasons (detailed at length) not food chlorophyll. The absence of parasitic algæ in sections of the livers of certain mollusks which yield enterochlorophyll shows that this pigment cannot be due to their presence. The writer further showed that Pocklington's opservations, published in the Pharmaceutical Fournal (1873), on the presence of chlorophyll in the wing-cases of Cantharides beetles, could be verified, and he had succeeded not only in verifying the presence of the principal chlorophyli band in the ethereal, chloroformic, and alcoholic solutions of the wing-cases, but the changes produced in the spectra of these solutions on the addition of certain reagents showed the presence of a body indistinguishable from vegetable chlorophyll. Hence Leydig's conclusion as to the presence of that colouring matter in insects was proved to be correct. However, in the case of green larvæ the mere occurrence of a band in red when a strong light is concentrated on the integument may be merely due to the presence of food chlorophyll in the intestine, for, on squeezing out the contents of the latter, the green colour and the band both disappear. The function of chlorophyll was then referred to : it was shown that it could hardly be of much use in respiration, as oxidising and reducing agents do not affect it ; that for protective purposes or in mimicry a body of less complex chemical composition might answer equally well, except that the eyes of some invertebrates may be more susceptible to rays of light of a certain wave-length than our own, especially as Sir J. Lubbock has shown that ants perceive the ultra-violet rays of the spectrum which are invisible to us. It may possibly be the persistence of a pigment which was once aseful in a remote ancestor in some cases, perhaps at a time when the atmosphere contained much more carbon dioxide than at present. Ur again, it may be of use in absorbing the chemically active rays of the spectrum when occurring on the surface of an animal, especially as Zimiriazeff had shown that Langley's observations with the bolometer have proved that the point of maximum energy of the solar spectrum corresponds with the principal chlorophyll band between $B$ and $C$. In the case of enterochlorophyll this colouring matter may be of use in furnishing material for the construction of other colouring matters, especially as this body and hæmochromogen exist side by side in the bile of some mollusks; and in the bile of the sheep and ox a body exists which fluoresces red and resembles chlorophyll closely, but possesses at the same time some properties which show that it is a hæmoglobin derivative, as proved by the writer (Proc. Roy. Soc. No. 208, 188o, and loc. cit.). The conclusions which had been arrived at gave support to the view which Prof. Lankester had maintained, namely, that chlorophyll may occur quite independently of the presence of parasitic algæ, as in Spongilla and Hydra, and that it is in some cases produced synthetically by and in the bodies of animals.

On the Intercellular Connection of Protoplasts, by Prof. W. Hillhouse.--In this paper the author gives the results of a large number of observations to prove the intercellular connection of protoplasm. Out of twenty-two plants examined, these connections were only found in the cortical tissue of Ilex aquifolium and Esculus hippocastanum, the pulvinus of Prunus lauroserasus, and the winter bud pith of Acer pseudoplatanus; he, however, points out that these connections are easily broken in preparation, and that a single connection between a number of cells would be sufficient to produce a perfect unity of action. His conclusions are $:-\mathbf{I}$. That protoplasmic threads connecting neighbouring protoplasts are present in such widely different and diffused structures as sieve-tubes, cortical parenchyma, Jeaf-pulvinus, pith of resting leaf-bud, and endosperm of seeds. 2. That in the contraction of the protoplast in natural plasmolysis these threads would normally remain unbroken. 3. That they may serve to transmit impulses from one cell to another, acting in this way somewhat like a nervous system. 4. That besides the perforating threads, equally widely spread and much more numerous, are threads which attach the protoplast to the cellwall, whether at the base of pits or otherwise, and that these threads are often opposite each other. 5. That the closing membrane separating two threads often shows differentiation, which suggests permeability, if not "sieve perforation." 6 . That in the contraction of the protoplast in natural plasmolysis these threads would naturally be unbroken. 7. That these threads may, when in extension, act upon the cell-wall and put it in a state of slight positive tension. 8. That the presence of minute perforations communicating from cavity to cavity of living cells would not, and when communicating with the intercellular spaces need not, be a hindrance to the turgipotence of the cells.

On the Continuity of Protoplasm through the Walls of Vegetable Cells, by Walter Gardiner.-The author, after briefly re viewing the work which has already been done in this depart ment, goes on to describe his own experiments with Mimosa Robinia, Dionæa, and other sensitive plants, and with thickened endosperms in general. In all organs of movement examined, the freely pitted parenchymatous cells were found to communicate with one another by means of delicate protoplasmic threads, which perforate the closing membranes of the pits. The author remarks that the existence of a communication between adjacent cells appears to be very wide, if not of universal occurrence. His own observations, extending over a series of fifteen species of palms and representatives of some thirteen orders, were all found to bear out the above researches, as in all cases definite and well pronounced continuity existed.

On the Muscular Movements that are associated zith certain Complex Motions, by R. J. Anderson, M.A., M.D. - When a nuscle contracts, one extremity or both extremities may move. When one extremity moves whilst the other is fixed, the fibre may describe a plane surface, as when the moving end lies in a right line or a cone, as when the moving extremity lies in the circumference of a circle or other plane curve. If the fibre lie in the plane of the circle, the cone will be reduced to a plane. Where both extremities move, the fibre may describe a plane, or a cylinder, or a ruled surface of a high order. It frequently happens that when one extremity of a fibre is fixed the other extremity moves in a circle, which itself experiences a movement of translation. The moving point then describes a trochoid, examples in pronator teres and pectoralis major. Muscle fibre may describe curves of a complex nature, although the muscles themselves form a simple surface, as in the two muscles already cited.

\section{SECTION G-Mechanical Scrence}

A Comparison of Morecambe Bay, Barrow-in-Furness, North Lancashire, West Cumberland, \&oc, in 1836 and I 883 , by Hyde Clarke.-The writer gave an account of his plans and surveys in I 836 for forming a through line of railway from Lancaster, through Furness and West Cumberland, across the Solway to Dumfries, and thence to Glasgow, by the course now adopted by the Glasgow and South-Western Railway. The chief feature was the passage and embankment of the large estuaries called Morecambe Bay. The history of this undertaking was given, with details of the plans of Messrs. Hyde Clarke, George Stevenson, Hayne, Rastrick, \&c., and the works carried out by Mr. James Brunlees. The plans of the Warton Land Company were described. The effect of the undertaking in the development of Barrow or Foudrey and the iron manufacture of Furness was illustrated. There were still 40,000 acres to be reclaimed, and capable of becoming good agricultural ground. If reclaimed it would enable a railway to be carried across the bottom of the Bay. There was now a population of 50,000 in Barrow, and although there had been great depression there were elements which pointed to a probable increase of from 100,000 to 200,000 persons.

The Term "Stability" as used in the Literature of Naval Architecture, by Prof. Osborne Reynolds. - The author explained that the origin of the paper had been the report and discussion which had taken place in regard to the lamentable disaster which happened to the Daphne. Stability meant a state of being able to maintain a particular position against any forces which tend to upset ; or another way of expressing the same thing was a state of ability to maintain a position after being disturbed and allowed to go free to recover itself again. It appeared from 
the report of Sir E. J. Reed on the Daphne lisaster, and the discussion which resulted, that naval architects were using the term stability both in its proper sense, as meaning a tendency to hold a particular position, and also as meaning a tendency to change position in a particular direction. The writer of the paper proceeded to urge the desirability of using two terms, the one to express the greatest angle of di turbance from which a vessel would return to her normal position, and to limit the quantitative meaning of the term "stability" to the measure of that angle, using the term "stiffness" to express the moment of the upsetting forces necessary to produce any particular angle of disturbance. The adoption of that system, which was consistent and definite, would prevent the confusion into $\mathrm{w}$ hich it appeared naval architects had fallen, and it would then be seen that what were ill-called curves of stability would be well-called curves of stiffness.

On the Construction and Working of Alpine Railways, by $\mathrm{J}$. B. Fell, C.E.-There are three Alpine railways in existence at the present time-the Mont Cenis and St. Gotbard Railways, which have been made with long summit tunnels and with ordinary gradients, and the Brenner Railway, that has been made with similar gradients but without a long tunnel. The important question has now arisen, and has been taken into serious consideration by the Governments and local authorities interested, as to how far it may be possible to make other trans-Alpine railways, some of which are urgently needed, at a cost that would render them financially practicable; and to accomplish this object it has been proposed to effect a reduction of one-half or more of the cost, by carrying these railways over the mountain passes by means of steep gradients and the use of the centre rail system, as it was adopted on the Mont Cenis Railway. Upon these improved summit railways the same weight ald number of trains could be run that are now running on the Mont Cenis Tunnel Railway, and with the protection of avalanche galleries and covered ways the regularity of the service would be maintained at all seasons of the year. The extra cost of working expenses caused by working over a higher level than that of a tunnel line would, if capitalised and added to the cost of construction, still leave a clear net saving of more than onehalf in the cost of construction as compared with the cost of a tunnel railway. The result of the experiences of the last twenty-five years seems to point to the conclusion that a method of constructing Alpine railways with long, non-paying tunnels is a thing of the past. The future belongs to the best system that can be devised for overcoming the difficulties of trans-Alpine railways rather by adding to the powers of the locomotive engine and by other mechanical appliances for reducing the cost of traction on steep inclines, which methods are capable of indefinite improvement, than by burying in gigantic tunnels enormous sums of unproductive capital that, when once expended, are irrecoverably lost.

The Euphrates Valley Railway as an Alternative Route to India, by J. B. Fell. - The author described the proposed route, and gave the total cost as $8,500,000 l$. He stated that, when not only its commercial but also its strategical and political advantages were taken into account, it must be admitted that the Euphrates Valley Railway certainly has the prospect of being one of the most successful enterprises in the world. Canon Tristram detailed his experience in the Tigris and Euphrates valleys, and stated that he believed the former to be the preferable route.

On Injector Hydrants, by J. H. Greathead.-This paper describea the method proposed for the author for meeting the serious increase of fires in the metropolis. A separate system of water supply at very high pressure would be laid under the footway with hydrants at short distances apart. The high pressure water would be used in conjunction with the ordinary water supply in the mains, and jets of water would thus be enabled to be raised to sufficient heights without the aid of fire-engines. The paper was illustrated by numerous diagrams, and elicited an interesting discussion, generally favourable to the author's views.

Nest Gearing, by Prof. Fleeming Jenkin.-This paper contained an account of a new friction gearing, the chief novelty being in the mode of obtaining any required amount of pressure between the wheels which roll upon each other. As many as thirty-two modifications have already suggested themselves, and the opinions expressed in the discussion were unanimously in favour of the invention as being a very valuable one.

Electric Launches, by A. Reckenzaun. - The paper commenced with a description of the launch Electricity, which made her first trip in September, 1882 . The Electricity is 25 feet long, with a
5 feet beam, and draws $2 \mathrm{I}$ inches forward and 30 inches aft. Her speed is 8.3 miles per hour with ten passengers on board. Forly-five Sell,n-Volckmar accumulators stored under the seats and decks forward and aft supplied the current to two Siemens $\mathrm{D}_{3}$ Series dynamos placed side by side on the floor of the baat, with their axes parallel to the propeller shaft. A Carliss-Browne two bladed propeller of 20 inches diameter and 3 feet pitch was employed in these first experiments; straps and pulleys were resorted to in order to reduce the speed of the screw to $35^{\circ}$ revolutions, whilst the motors revolved at 950 revolutions per minute. The two motors were coupled in parallel circuit, whereas the cells formed onc series. Each machine had its own switch and ammeter, and the starboard machine could be stopped mechanically by means of a friction clutch on the countershaft. Both machines were tested with a Prony brake, and they gave I. 86 horse-power on the brake at 950 revolutions, consuming a current of 21 amperes and 100 volts. At 694 revalutions, roo volts and 33.25 amperes, the brake horse-power rose to 2.78 . With 47 cells on board, the current used by both motors running together was 46 amperes, and the propeller made 360 revolutions; when clisconnecting one of the motors the current passing through the other was 33 amperes, and the speed of the propeller shaft fell to 250. Messrs. Siemens' dynamos lend themselves very readily to the purposes under consideration; the height of a $\mathrm{D}_{3}$ machine is only 10 inches, length 28 inches, and width 23 inches. The two machines weigh together 632 lbs., countershaft, supports, and pulleys $180 \mathrm{lbs}$, total for the driving apparatus 8 i 2 lbs.

Electric Launches, by J. Clark. - This paper contained a very brief account of advances in this subject.

The Fire Risks of Electric Lighting, by Killingworth Hedges. - The author first drew attention to the great difference between the electric currents which have been in constant use for telegraphic purposes and those which are to be supplied by the undertakers under the Electric Lighting Act. The latter can only be said to be free from danger when the heat generated by the current is utilised in its right place, and not developed in the conductors or wires which lead the electricity to the incandescent lamps. The Fire Risk Committee have already issued rules for guidance of users of electric light; thesc can hardly be said to embrace all the salient points of the new subject, which can only be arrived at after years of practical work. The necessity of proper regulations has already Deen recognised by the insurance offices, both in the United States and Germany, and some of their special rules are given in this paper. The conductors must be properly proportioned for the current they have to carry ; whatever resistance there is in the conductor will cause a corresponding development of heat, which will vary with the amount of electricity passing, and inversely as the sectional area. As the temperature in Dr. Matthiessen's experiments upon the subject was not increased over $100^{\circ} \mathrm{C}$, the author has made some further experimentsheating the wires by the electric current from a secondary battery to within a few degrees of their melting-point. Various materials were tried-the wires and foils having such sectional area, and so arranged that, on the current being increased by 20 per cent., they were immediately fused. The total length of each experiment was twenty-four hours, during which time the current passing through varied slightly. The results of the experiments were then given.

\section{SCIENTIFIC SERIALS}

Archives of the Physical and Natural Sciences, Geneva, September 13.-Verification of some atomic weights (second memoir); zinc and magnesium, by $M$. C. Marignac. The atomic weight of zinc, fixed by Erdmann at $65^{\circ} 05$ and by Favre and Jacquelain raised to 66 , is approximately determined at $65^{\circ} 33$, a figure which further analysis may show to be slightly too low. For magnesium, calculated by MM. Marchand ard Scheerer at 24 and by others at $24^{\circ} 5$, the number $24^{\circ} 37$ results from the author's fresh experiments. - Essay on the protistology of Sardinia, with a description of some new or little-known lower animal organisms, by Prof. Corrado Parona. In the fresh and marine waters of Sardinia the presence is determined of as inany as 228 species belonging to the families of Bacteria -Monera, Flagellata, Lobosa, Diatomea, Heliozoa, Ciliata, Acineta, and Catallacta. The paper is accompanied by seven illustrations.-Memoir on earthquakes and volcanoes (continued), by Prof. F. Cordenons. In this second and concluding part the 